\title{
The Role of Local Government Areas in Rural Transport Financing
}

\author{
G. Ademola Olukotun \\ Department of Finance and Banking, Faculty of Management Science, Kogi State University, \\ Anyigba, Nigeria \\ Telephone: 234(0)8062995674, E-mail: olukgaby@yahoo.com
}

KEYWORDS Local government; financing;rural transport; communities

\begin{abstract}
The Local Government Area is the closest level of government to the rural communities. These rural communities are characterized by traditional use of resources and implements, involuntary idleness of the population from time to time, dearth of infrastructural facilities, and, social amenities, limited capacity for social and vehicular mobility etc. Yet, a greater percentage of the population live there and the rural areas also serve as the food basket of the nation. To get over their problems, the rural communities look up to the Federal, State and Local Government Areas. However, they look more to the local government since it is the closest to them for the provision of good roads, electricity, schools, health centres etc. One area that the local government area has to seriously address to bring relief to the local government areas is the provision of credit facilities to the rural dwellers for transport. This it is hoped will ease human mobility and the evacuation of farm products.
\end{abstract}

\section{INTRODUCTION}

No central government can successfully conduct any meaningful administration only through the capital city based servants without decentralizing some of its activities in order to eliminate delays often experienced at the headquarters. This implies that there is need for a form of government to reach out to the people at the grassroots level.

The Local Government System is the closest form of government to the grassroots and therefore, a properly organized local government system under which the people of a particular area could be involved in running their affairs is considered more acceptable. This is because, the impact of the local government is felt more at the grassroots than a centralized form of government where government officials, who may not have the requisite knowledge of the local environment are in control.

In other words, the local government system is one of the numerous forms of decentralization adopted by modern governments and this enables the welfare of the people at the local level to be adequately catered for, and also provides opportunities for local officials to attend to the numerous problems confronting the local communities.

\section{IMPORTANCE OF THE LOCAL} GOVERNMENT AREAS (LGAS)

According to Oyeneye, Onyenwenu and
Olosunde (1998), Local Government "is a government at a local level, established by an act of parliament, statute, decree or edict, charged with administrative and executive duties on matters concerning the inhabitants of a particular district, and given the powers to make bylaws for their purpose".

Among the reasons for the creation of Local Government include according to Oyeneye et al. (1998) the following: -

i. Participatory democracy

ii. Bringing government closer to the people

iii. Equitable socio-economic development.

iv. Choice of leadership

v. Familiarity

vi. To serve as link between the people and the government

vii. Experimentation of government policies

Decree 12 of 1989 clearly spelt out the importance of LGA's in Nigeria. Similarly, the fourth schedule (Part 1) of the decree also spelt out in details the functions of the L.G.As. According to Adeniji-Adele and Davies (1993). LGA's have exclusive and concurrent functions and these can be divided into four functions namely regulatory and licensing, social service, protective and economic functions respectively. Expatiating further on the social service function as it relates to transport they said "one of the many ways by which local governments can bring about social and economic transformation of their areas is to evolve a transport programme by which movement of persons and goods becomes easier". 
In his forward to the 1976 local government reform guideline, the late Major-Gen. Shehu Yar'adua (Rtd) argued that "the reform of our local government system is aimed at the involvement of the rural people in decision making on developmental efforts which affect them. It also includes the contribution of their resources to development activities as well as the assurance that the rural people will benefit from interventions intended to help them, and ensure rural development and transformation".

The report of the Political Bureau (1987) also observed that "Local Government is widely acknowledged as a vital instrument for rural transformation and for the delivery of social services to the people". This arises from the fact that "the physical and psychological distance between officials of the other tiers of government and the people frustrate efforts in making people fully identify with government programme. People at the grass-root are only able to understand and recognize local governments because they are able to feel its presence and impact on their day to day activities. This therefore makes the LGA's very unique.

From the above therefore, one will agree with Farah (1995) that one of the principal objectives of having a local government therefore is to provide social services of all kinds to meet some specific needs of the local people. This is because, a local authority has the knowledge and time to concern itself with details of this nature.

\section{BRINGING GOVERNMENT CLOSER TO THE PEOPLE THROUGH THE CREATION OF LGAS}

The Federal Government has always been desirous of bringing government closer to the people. One of the tools they have consistently used is the creation of Local Government Areas (LGAs). As far back as 1976, the Obasanjo Administration addressed the issue through the local government reform which tackled the issue of local government structure, composition and funding.

As at 1976, 1981, 1987, 1991, 1992 and 2001, there were 299, 781 (created by civilian administration but dissolved by the military), 449 , 580,589 and $774 *$ local government areas in Nigeria respectively (Obinna, 1995*) not included in data.

According to Aikhomu (1993), "in fact, the number of local government rose significantly from 449 to 589 in an attempt not only to bring government and development nearer the nooks and corners of Nigeria but also to generate political awareness and mobilization and hence, political participation as the bedrock of a new democratic order".

When the population of Nigeria was about 100million people in 1996, there were 589 local government areas (LGAs) making it an average of 169779 people per local government. By the year 2001, with an estimated population of about 120million people and 774 local government areas, the average population per local government was 155,039 . This is a decrease and an evidence of the fact that the government is desirous of bringing its activities closer to the grass-root.

Even, when we take a look at the actual population distribution per local government obtained from the Annual Abstracts of Statistics (1991 and 2001), population density per local government is on the decrease. See table 1 for the analysis.

Table 1: Population density in the LGA's of Nigeria (1991 \& 2001)

\begin{tabular}{|c|c|c|c|c|c|}
\hline \multicolumn{3}{|l|}{ 1991-541 LGAs } & \multicolumn{2}{|l|}{2001774 LGAs } & \multirow[b]{2}{*}{$\%$} \\
\hline Population('000) & No. of LGAs & $\%$ & Population('000) & No. of LGAs & \\
\hline $0-100$ & 138 & 25.5 & $0-100$ & 374 & 48.3 \\
\hline $101-200$ & 274 & 50.6 & $101-200$ & 340 & 44 \\
\hline $201-300$ & 96 & 17.7 & $201-300$ & 39 & 5 \\
\hline $301-400$ & 20 & 3.6 & $301-400$ & 11 & 1.4 \\
\hline $401-500$ & 3 & .6 & $401-500$ & 8 & 1 \\
\hline $501-600$ & 1 & .2 & $501-600$ & 2 & .3 \\
\hline $601-700$ & 4 & 8 & & & \\
\hline $701-800$ & 2 & 4 & & & \\
\hline $801-900$ & 1 & .2 & & & \\
\hline $901-1,000$ & 1 & .2 & & & \\
\hline Above 1 million & 1 & 2 & & & \\
\hline Total & 541 & 100 & Total & 774 & 100 \\
\hline
\end{tabular}

Source: Annual Abstract of Statistics (Federal Office of Statistics) 1996 and the National Population Commission. 
From the above, it is clear that the population density per local government is on the decrease. While in 1991 only 138 LGA's have population density of between $0-100,000$ people, it has increased to 374 LGA's by the year 2001. For the 101000 to 200,000 population density, while in year 1991 , there were only 274 LGA in the year 2001 , there were 340 . Looking at the table also since year 2001, there is no local governments area in the country with a population density of more than 600,000 but that was not the case in 1991 .

In fact, as far back as 1976-1977, 21 local government areas 1 each in Benue, Niger and Kaduna States) 2 each in Bauchi, Anambra, Plateau, Rivers and Cross Rivers States and 4 each in Borno and Bendel States had population density of less than 100,000 people (Obi, 1995).

In the developed countries of Western Europe, this is slightly different. According to Emielu (1996), whereas today while over half of the population of North America and Europe live in cities of at least 100,000 people, in South America, about one third of the people live in cities of at least 100,000 people. In fact, Netherlands and Belgium have population densities of over 300 persons per square kilometer.

\section{IMPORTANCE OF RURAL TRANSPORT}

A greater percentage of the Nigerian population lives in the rural areas and they are mostly farmers, engaged in subsistence agriculture. These rural dwellers produce the food consumed in the cities and most of the agricultural raw materials used by the industries. In other words, without further development of their rural areas, it is unlikely that the majority of sub-Saharan African countries will be able to feed their people, develop industries based on their primary agricultural products, provide adequate employment or sustain current levels of foreign exchange earnings from their exports. Unfortunately however, the transports needed to evacuate these goods are not available/adequate.

Road transport covers the widest network in Nigeria. It is easy to expand and it provides the most flexible services. It can provide origin to destination service without transshipment (Ukwu, 1990).

Rural infrastructure constitutes the substance of rural welfare. Efforts to raise rural welfare must necessarily go beyond the limited approach of raising per capital income through agricultural developments but also to the provision of rural transport facilities (Idachaba, 1985).

All over the world, Poverty reduction in the rural areas is tied to rural transport and it remains the central goal of global development efforts. Even in South East Asia, Rural communities face transport constraints which limits their ability to reduce their poverty and in order to satisfy their need for greater access to health, education and every possible opportunities, ease of physical accessibility and freedom of movement are top priorities.

Even, to the physically disabled, access to transport can substantially transform their lives and that of their immediate families. These people are recognized as vulnerable population due to their double penalty of social discrimination and physical exclusion which often traps them in poverty resulting mostly in most of them begging. Inaccessibility to transport can make it difficult for them to find employment, gain education and access healthcare as well as limiting their social and recreational activities.

The importance of Rural Transport therefore include the following:-

1) Accelerate the delivery of farm inputs and the services of extension workers

2) Preventing excessive rural to urban migration with the attendant problems

3) Facilitate the evacuation and marketing of produce from agriculture, fishing and livestock

4) Ease of human movement within and outside the community, thereby reducing or eliminating repetitive movement and thereby increase in residual time for other activities

5) Enhance the effectiveness of public policy

6) Reduce the level of wastage of agricultural products and thereby bring about a reduction in their prices

7) Mobilizing the vast natural and human resource potentials of the rural sector

8) Accelerate the delivery of basic needs to the rural majority

9) Helps the local populations regain their lost ability of self-reliance especially in the area of food production

10) It will facilitate flow of information, diffusion of innovation and exchange of ideas which invariably lead to the introduction and adoption of new ideas and new techniques capable of catalyzing the mechanism for more effective operation and management of resources (Sumaila, 1998) 
Despite all these however, it is very ironical that many rural communities in Nigeria still lack good roads and consequently find it difficult to transport their goods. It even becomes difficult and at times impossible to reach some rural communities during the rainy season due to the bad terrain of some roads or collapsed bridges. In most cases, the vehicles needed in transporting the farm products are not available. Where they are available, they are often rickety and lack the strength and "courage" to work.

These conditions has in most cases resulted in longer journey times, higher fares, delayed journeys, unnecessary consumption, high cost and destruction of farm products and the increased risks of major delays.

\section{THE ROLE OF THE LOCAL GOVERNMENT AREAS}

The enormity of transport burden undertaken by the rural communities to meet their basic needs and the degree of its inhibiting their social and economic developments cannot be underestimated. Poor access results not only in isolation but also a constraint to productive activities.

Transport is seen as a facilitator of development. Access intervention by the local government areas in the form of loan for rural communities will not only diminish the socio-economic isolation of the rural population, it will also contribute to the reduction of their poverty.

Almost all the LGA's have their mass transit schemes in place. All these vehicles engage in inter and intra state movements. The unfortunate thing however is that most of the vehicles bought and owned by the local government areas are of little benefit to the rural dwellers. This is because most of the vehicles move from the local government headquarters to the State headquarters leaving the rural people unattended to. The tragedy of the whole transport system so provided by the LGA's is that most of the vehicles do not operate within the rural communities.

The vehicles are brought from the local government allocations and no individual can claim ownership. This therefore put the drivers in the best position to be unfaithful. Most of them make do with half or quarter full of passengers in order to pick the remaining passengers along the way (and the money of course goes to the drivers).

In a chart I had with 15 local government drivers in five LGA's of Kogi State said they were not happy when their vehicles were fully loaded from the garages. Most often, they engage in one or two sharp practices (including lying and unlawful damage) in order to make their own money since they alleged, "everybody is making his own money". In the spirit of the current privatization exercise, the various governments are encouraged to hands off their direct participation and provide the needed funds and enabling environment and legislation.

According to Adeniji-Adele and Davies (1993), while appraising the mass transit scheme of Lagos Island Local Government Area of Lagos State, they gave the problems associated with the scheme as:

a) "High cost of vehicle which makes it difficult for the Transport Company to replace old and unserviceable vehicles.

b) Lack of spare parts, which affect maintenance work

c) Lack of regular fuel supplies

d) Fraud perpetrated by operators

e) Logistic problems

f) Management problems; and

g) Will full damage of company property"

This is the case almost everywhere. From history, private organization does it better with the exception of a few cases of Edo and Delta State Governments. Most of the states' transport companies in existence before the present civilian government came into existence in 1999 have collapsed due to fraud and mismanagement. In fact, in some cases, some vehicles needing brake pad/battery has to be parked for 9-12 months because a 2-3 page memo has to be written to justify the need for a good battery/brake system in the vehicle owned by the Local and State Governments.

In the light of the above therefore, the local government should intervene as follows:

i) They should set aside a given sum of moneyabout N5million as vehicle loan to individuals and groups in each community in their areas from their monthly allocation from the government. This will ensure that at least each community will have a vehicle to meet their transport needs for the movement of people and the evacuation of goods. The loan can also be given to cooperative groups or community Development Associations in the various LGA's.

ii) Another option is for the local government areas to buy the vehicles and lease them to the communities 
iii) The councilor representing the benefiting community and the Chief/Emir or the cooperative group officials should serve as guarantors for the loan. The local governments can also work through the existing money lenders who already know the credit worthiness of the local people and can help to reduce risks and administrative cost (Ellis, 1997). This will ensure monitoring and thereby reduce the rate of default

iv) The borrower should be made to pay back the money to a designated bank and it should be made a revolving loan. This will ensure that it is repaid for the benefit of other people in the communities. The local government officials should crosscheck the repayment made with the banks

This scheme has support in the fact that those local development strategies and approaches need to be attuned to the specific conditions prevailing in the rural areas of different states/ countries with diverse conditions. In other words, indigenous technical knowledge including organizational resources, which is a major unutilized resource, should be tapped.

Secondly, this scheme has support in the fact that "Ajo" "Esusu" and cooperative which are common among the rural people have become veritable tools for resource mobilization and allocation and is consistent with the Nigerian culture of assisting the less privileged.

For the above scheme to succeed however, certain conditions must be fulfilled (Mosley and Hulmes, 1994). They are:

a) The lending institution (local government) should be allowed to pass the full cost of borrowing to the borrower

b) Loan installments should be collected frequently i.e. weekly so that default can be quickly detected and corrected

c) Positive incentive should exist for repayment i.e. rebates to borrowers for full repayment. The full repayment should also be publicly acknowledged

d) Lenders (local governments) should be insured against default

e) The system should require that borrowers save. This is because, it is very common in developing countries for vehicles to be out of service/use, not because of lack of spares but because adequate provision has not been made on the part of the operators for the eventuality of a breakdown. The fact that there could be cases of default should not deter the LGAs from going ahead with the scheme

The benefits of the above scheme to the rural communities, the local government areas and the country at large cannot be over-emphasized because:

1) It will create employment. Even if the absolute number were small, legitimate employment and income would have at least been opened up for Nigerians

2) It will assist in the evacuation of farm products and movement of people from the rural communities

3) It will help in reducing rural povertyconsequent upon the multiplier effect of the fund injected into the communities and the income generated there from

4) It will ensure a better working relationship between the local government areas (LGA's) and the rural communities since the LGA's are now seen as partners in progress. The rural communities will also see the local government issues/problems as their own instead of the current non-challance that obtains

5) It will reduce financial wastage as presently obtained in the LGA's. This is because not all the money generated from the scheme goes to the LGA's

6) It will make the government more responsive

7) It will make the allocation of development funds more responsive to the needs of the rural communities

8) It will improve the targeting of rural poverty programmes and finally

9) It will strengthen the capabilities of the citizenry to undertake self-initiated development activities

The fact that there could be defaulters should not deter the local government areas from going ahead with the operation of the scheme. It should only strengthen them to make their disbursement more stringent and their monitoring very responsive. It is the fear of default above all things that should make the scheme succeed.

To be able to finance the scheme the LGA's should engage in revenue yielding/conserving activities such as the use of direct labour for project execution, establishing permanent revenue generation organs, engage in equipment leasing leasing and in the operation of buffer stock system for agric products etc (Ademu, 1995).

In Zimbabwe about $75 \%$ of the population live in rural areas and they have difficult access 
conditions (Lema, 2003). A survey was carried out in two of their districts. One of the principal objectives of the survey was to determine the access intervention needed by the rural people and to seek for possible solution. One of the interventions implemented was "the provision of a loan scheme to acquire intermediate means of Transport" (IMTS). The result from the loan provision was the ability to carry greater loan fund". Another was that income generated through hiring out IMTS and the income realized has assisted the ability of the poor household to buy basic necessities.

\section{CONCLUSION}

If the above scheme (credit) is put in place by the Local Government Areas (LGA's), it will ease transportation problems in the rural areas both for human movement and for the transportation of goods from the farms to the market.

But the LGA's in doing this should use a community driven development approach (CDD approach). This involves the communities having direct control over the project decision making including the management of the investible funds. It also involves the utilization under one single programme of approaches and techniques which rely upon local communities as units of action and which attempt to combine outside assistance with organized local self-determination and effort and which correspondingly seek to stimulate local initiative and leadership as the primary instrument of change.

This scheme therefore enhances sustainability, improves efficiency and effectiveness, makes development more inclusive, empowers poor people, strengthens governance etc. This is because CDD reduces information problems, expand resources available to the poor (through credit) and strengthening the civic capacities of the communities by nurturing individuals and organizations that represents them.

In conclusion, in the word of Sumaila (1998), all these efforts would make planning more pragmatic with positive implications for the achievement of more efficient allocation of rural resources, and the overall development of the rural area".

\section{REFERENCES}

Ademu, W. A. 1995. The Search for Financial Autonomy in Local Government areas in Nigeria. Readings in contemporary economic issues, Department of
Economics, University of Jos, Mono Expressions. Adeniji-Adele E. and A. E. Davies. 1993. "Local Government Involvement in Mass Transit Service in Nigeria", (pp. 208-222) in S. G. Ikya (ed.), Urban Passenger Transportation in Nigeria. Ibadan: Heinemann.

Aikhomu A. A. 1993. "Federal State Relationship under military government (1985-1992)." The Nigerian Journal of Federalism, 1(1): 3-6

Dennis, R. 1998. "Rural Transport and Accessibility." A Synthesis Paper. Rural Accessibility Technical Papers No. 1, Geneva: ILO.

Ellis, S. D. 1997. Key Issues in Rural Transport in Developing Countries. Crowthorne Berkshire U.K.: Transport Research Laboratory Report 260.

Emielu, S. A. 1996. Senior Secondary Geography. Ilorin: Geographical Bureau.

Farah, B. S. 1995. The Role of Local Government Councils in the Development of Transportation in Nigeria. A Postgraduate Diploma Project submitted to the NITT, Zaria

Federal Republic of Nigeria. 1976. Guidelines to Local Government Reforms. Kaduna: Government Printer.

Federal Republic of Nigeria 1987. The Report of the Political Bureau. Lagos: Federal Government Printer.

Federal Republic of Nigeria. 1999. The Constitution of the Federal Republic of Nigeria. Abuja: Federal Ministry of Information.

Howe, J. and P. Robert. 1984. Rural Roads and Poverty Alleviation. London: IT Publications.

Idachaba, F. S. 1985. Rural Infrastructure in Nigeria. Ibadan: Ibadan University Press

Institute for Development Studies, Nairobi 1987. East African Rural Development Experience. Proceeding of International Seminar, Kenya: University of Nairobi.

Lema, C. 2003. Assist. Geneva: A publication of the International Labour Organization (ILO).

Mausuri G and V. Rao. 2004. "Community -Based and Driven Development A Critical Review." Research Observer. A Publication of the World Bank, 19(1): 1-31

Mosley P. and D. Hulme. 1994. Effective Financial Institutions for Lending to the Poor. Brighton: Development Research Insight For Policy Makers ODI-IDS Publication.

Obi, M. A. O. 1995. "The Structure of Local Government in Nigeria.", (pp. 74-82), in B.O.Folaranmi (ed.), Local Government Administration in Nigeria: Current Problems and Future Challenges. Lagos: Academy Press.

Obinna E. O. 1995. Local Government finance", (pp. 38-56), in B.O.Folaranmi (ed.), Local Government Administration in Nigeria: Current Problems and Future Challenges. Lagos: Academy Press.

Oyeneye, O., P. Onyenwenu and K. Olosunde. 1998. Government - A Complete Guide. Ibadan: Longman Nig. Plc.

Sumaila, A.G.F. 1998. "Transport and Rural Development." The Trainer, 1(4):22-28 1998-Jan. 1999.

Ukwu, I.U. 1990. "Transport and National Development", in Ola Adegbeyeni and O. J. Rapu (eds.), Transport Management For National Development. Lagos: B. G. Publishers.

World Bank. 1994. Rural Infrastructure for Development. World Bank Report. Washington D.C.: World Bank. 